УДК $902 / 552$

https://doi.org/10.24852/2587-6112.2021.4.122.129

\title{
ОСОБЕННОСТИ ОТБОРА И ПОДГОТОВКИ СЫРЬЯ ГОНЧАРАМИ БОЛГАРА: РЕЗУЛЬТАТЫ ПЕТРОГРАФИЧЕСКОГО АНАЛИЗА
}

\author{
(C) 2021 г. А.А. Куклина, О.Ю. Андрушкевич
}

Исследование вопросов технологии является одним из приоритетных направлений в изучении гончарства Волжской Булгарии. Петрография значительно дополняет результаты, полученные с помощью классических методов археологии. В ходе проведенных исследований петрографических шлифов керамики I группы Болгарского городища были получены данные относительно трех основных параметров: глинистое вещество, примеси (искусственные и природные) и поровое пространство. В процессе были определены некоторые закономерности использования гончарами Болгара различных видов исходного сырья. Исследование минеральных примесей позволило сделать некоторые выводы о его источниках. Различные виды поровых образований, зафиксированные в шлифах общеболгарской керамики, дают представление о технологии сушки и обжига изделий. В целом результаты петрографии подтверждают сделанные ранее наблюдения об использовании различных видов сырья и технологических приемов в среде гончаров, изготавливавших керамику I группы в Болгаре.

Ключевые слова: археология, петрография, Средневековье, Болгарское городище, керамика, гончарное производство, источники сырья, примеси, пористость.

\section{SPECIFICS OF SELECTION AND PREPARATION OF RAW MATERIALS BY BOLGAR POTTERS: PETHROGRAPHIC ANALYSIS RESULTS}

\section{A.A. Kuklina, O.Yu. Andrushkevich}

Technology issues are priority directions in the study of Volga Bolgaria pottery. Petrography significantly complements the results obtained using classical methods of archaeology. As results of the petrographic analyses of the I group of ceramics from Bolgar fortified settlement, data were obtained for the following three main parameters: clay matter, impurities (artificial and natural) and pore space. In the process, certain patterns were determined in terms of the use of various types of raw materials by Bolgar potters. A study of mineral impurities has allowed to draw conclusions about its sources. Various types of pore formations identified in thin sections of common Bolgar ceramics provide insight into the technology of drying and firing of the products. In general, petrography results confirm the earlier observations concerning the use of various types of raw materials and technological methods by the potters who crafted group I ceramics in Bolgar.

Keywords: archaeology, petrography, the Middle Ages, Bolgar fortified settlement, ceramics, pottery, raw material sources, impurities, porosity.

Гончарная керамика средневекового Болгара изучается и анализируется уже много лет. В ряде работ, посвященных этому предмету и ставших уже классическими, поднимались вопросы морфологии форм и технологии гончарного производства. Поскольку большую часть в керамическом комплексе Болгара, как и многих других памятников, составляет I группа керамики, выделенная Т.А. Хлебниковой, неудивительно, что именно эта категория находок стала объектом пристального внимания. Вопрос о неоднородности I группы керамики также поднимался, и на основании накопленных результатов предшествующих исследований была предложена методика выделения подгрупп общеболгарской керамики (Куклина, 2018, 2020). Поскольку эта методика разрабатывалась для того, чтобы можно было описывать большие объемы керамиче- ского материала, она основана на тех признаках, которые видны невооруженным глазом (или с небольшим увеличением). В связи с этим возникла необходимость уточнения ряда технологических вопросов относительно особенностей исходного сырья и подготовки формовочных масс. Метод петрографии уже стал классическим для исследований такого рода. Масса публикаций, освещающих результаты изучения археологической керамики с применением петрографии, является тому доказательством (Внуков, 2006; Бахматова, Куклина, 2014; Кулькова, 2015; Герман, Кулькова, 2019).

Цель исследования заключалась в определении степени различия общеболгарской керамики по трем основным группам признаков: глинистому веществу (матриксу), природ- 
ной и привнесенной примеси и поровому пространству.

Первая группа - глинистое вещество характеризует свойства исходного глинистого сырья и отображает природную составляющую керамического изделия.

Вторая группа - примеси - характеризует все имеющиеся включения, определяется в шлифе в виде обломочного материала различной морфологии и генезиса, отображает как природную, так и искусственную (привнесённую гончаром) компоненту.

Третья группа характеризует поровое пространство и определяется в шлифе в виде пор и пустот разнообразных размеров и форм, отображает исключительно техногенную (возникшую в процессе изготовления гончарного изделия) составляющую.

Для этой цели были отобраны образцы 12 подгрупп общеболгарской керамики (1т, 2т, 3т, 4т, 5т, 1л, 2л, 3л, 4л, 5л, 6л, 7л) и общеболгарской керамики «восстановительного обжига» (с черным черепком) из объектов домонгольского и раннезолотоордынского времени с раскопа CXCII Болгарского городища - всего 126 шт., размером от $5 \times 5$ до $10 \times 25$ мм $^{1}$.

Первая группа признаков - глинистое вещество.

Изучение глин в петрографическом микроскопе уверенно диагностирует следующие параметры: цвет и интерференционную окраску (в параллельных и скрещенных николях), степень поляризации глинистого вещества (степень кристалличности), особенности микро- и макростроения (микротекстура, слоистость, однородность), наличие обломочной примеси. Остановимся подробно на каждом из перечисленных параметров.

Цвет. В целом для большинства исследуемых образцов в шлифах характерен коричневый цвет с многочисленными вариациями: от желтоватых, светло-коричневых тонов до красно-коричневого, бурого и тёмно-коричневого цвета. В незначительном количестве шлифов отмечаются оттенки серого цвета.

Цвет подавляющего большинства шлифов определяется присутствием в образцах минералов из группы гидроокислов железа. Именно эти минералы при обжиге дают характерные красно-коричневые цвета.

В шлифах единичных образцов (подгруппы 7л и «восстановительного обжига») глинистое вещество окрашено в тёмно-бурые, практически чёрные цвета, что делает его непрозрачным и существенно снижает возможности его микроскопического исследования.
Особенности строения. При анализе структуры глинистого вещества в исследованных шлифах каких-либо специфических особенностей для отдельных групп образцов выявлено не было. Большая группа исследованных шлифов содержит своеобразные сгустки и комки, которые легко обнаруживаются в первую очередь по разности цвета между ними и вмещающей матрицей. Нередко подобные образования имеют и отличный от вмещающей породы облик обломочной примеси: иную концентрацию, другой минеральный состав и размер обломков.

Для исключения неопределённости в терминологии предлагается использовать термин “сгустки” для природных включений и термин “комки” для искусственно введенных образований. Последние представляют собой кусочки перетёртой необожжённой глины, добавляемой гончаром в исходное тесто.

Достоверное разделение природных сгустков глины от антропогенных комков (перетёртой необожжённой сухой глины) возможно при наличии трёх основных факторов:

1. Границы образования: в подавляющем большинстве случаев для комков характерны резкие отчётливые границы, наблюдаемые даже при больших увеличениях, для сгустков более типичны расплывчатые, размытые, прерывистые очертания, нередко теряющиеся при значительном увеличении.

2. Наличие “пор облегания". Большинство комковатых образований имеют либо прерывистую, либо полную оторочку поровым пространством. Толщина такой оторочки составляет десятые (иногда сотые) доли миллиметра и отчётливо наблюдается только в окрашенных шлифах (рис. 4: 4.)

3. Изменение в поляризации вещества. При наблюдении в скрещенных николях для комков характерно "усиление" отличия от вмещающей породы. В противовес этому сгустки часто пропадают или становятся практически не видны. Объяснение этому достаточно простое: природные сгустки, в силу геологических особенностей, не могут существенно отличаться по минеральному составу от вмещающей породы. При обжиге оптические характеристики минералов сгустка и основной массы гончарного теста меняются примерно одинаково. С другой стороны, искусственно привнесённые комки изначально могли иметь иной источник сырья с другим составом глинистых минералов. Поэтому при обжиге изменение степени поляризации 
происходит по-разному, что приводит к усилению оптических различий в поляризованном свете.

Размер комков может изменяться в широких пределах от 0,2-1,0 мм до 10-15 мм, для сгустков характерны несколько большие размеры, от 2-3 до 20-25 мм.

Однородность глинистого вещества характеризуется отсутствием в основном матриксе шлифа внутренних микроструктурных несогласий. За достоверно устанавливаемое однородное глинистое вещество принимался такой матрикс, в котором не обнаруживалось видимых в микроскоп явных цветовых переходов, заметных различий в степени поляризации на соседних участках шлифа, очевидных переходов к различным микроструктурам (чешуйчатость, волокнистость и т. п.). В противоположность однородному глинистому веществу выделялось сгустковое. Достоверность выделения сгустков в глинистой матрице определялась наблюдением в поле всего шлифа одного крупного (не менее 3-4 мм) или множества мелких (1-2 мм) сгустков. По итогам исследования во всех шлифах выделено два типа глинистого вещества: однородное и сгустковое. При этом не обнаружено очевидной зависимости между образцами подгрупп «т» (изготовленных с помощью вытягивания на круге) и подгрупп «л» (изготовленных с помощью навыков скульптурной лепки и заглаженных с помощью вращения круга) и однородностью глинистого вещества. Наиболее однотипными по первичному сырью оказались подгруппы 2т, 1л, 3л, 4л, 6л и керамика восстановительного обжига, где фиксируется преимущественно сгустковая глина, и подгруппы 1т и 2л, где в основном зафиксировано однородное сырье. Отметим, что только для одной подгруппы - 5т - установлено использование исключительно сгусткового сырья. В остальных исследованных подгруппах - 3т, 4т, 5л, 7л - наблюдается и сгустковое, и однородное сырье - примерно в равных долях.

Вторая группа признаков - обломочная примесь.

По общему характеру обломочной примеси можно выделить следующие группы.

1. В шлифах доминирует равномерно распределённый обломочный материал алевритовой и тонкопсаммитовой размерности (пример - образец 7л № 3852, рис. 1: 1).

2. Для шлифов характерна обломочная примесь преимущественно тонкопсаммитовой размерности, распределение в матриксе образца часто неравномерное (пример - образец 1л № 30.2, рис. 1: 2).

3. Незначительное содержание равномерно распределённого обломочного материала различных гранулометрических групп от тонкоалевритового до псаммитового (пример - образец 7л № 22.5, рис. 1: 3).

4. В шлифах отмечается небольшое количество алевритового материала и значительная примесь псаммитовых частиц различного размера, распределение неравномерное (пример - образец 2л 38.2, рис. 1: 4).

Диагностика обломков минералов и горных пород является достоверной тогда, когда определение проводится на зёрнах крупного размера (от 0,3-0,5 мм и больше). Наиболее часто встречающиеся минералы: основной плагиоклаз, кислый плагиоклаз, микроклин, мусковит, амфибол. Их общее количество не превышает в шлифах 2-5\% и не является значимым для дальнейших выводов. Доминирующим минералом в составе обломочного материала исследованных шлифов является кварц. Он представлен зёрнами различных размеров: от алевритовых (0,01-0,05 мм) до крупнопсаммитовых (1,0-2,0 мм). По степени окатанности в алевритовой компоненте доминируют слабо окатанные, угловатые, иногда оскольчатые зёрна, в крупных разностях преобладают окатанные и хорошо окатанные зёрна.

По особенностям оптических характеристик можно выделить две разновидности кварца: зёрна с ясным равномерным погасанием (рис. 2: 1) и кварц с волнисто-облачным погасанием, так называемый давленый кварц (рис. 2: 2). Первый кварц заметно преобладает в большинстве исследованных шлифов.

Разделение привнесённой примеси по источникам сырья

Следующим вопросом, который рассматривался в ходе исследований шлифов, был вопрос о возможности идентификации источников сырья. Интересное направление дальнейших работ показало исследование крупной песчаной фракции (0,5-2,0 мм). В шлифах, в которых устанавливается “антропогенная" псаммитовая составляющая, наметилась следующая закономерность. Если минеральный состав алевритовой и мелкопсаммитовой примеси всех исследованных шлифов практически однороден, то крупные обломки минералов и горных пород, вероятнее всего, можно будет разделить на две группы. В составе обломков первой группы значительно преобладают хорошо окатанные кварцевые зёрна с чистым недавленым кварцем. 


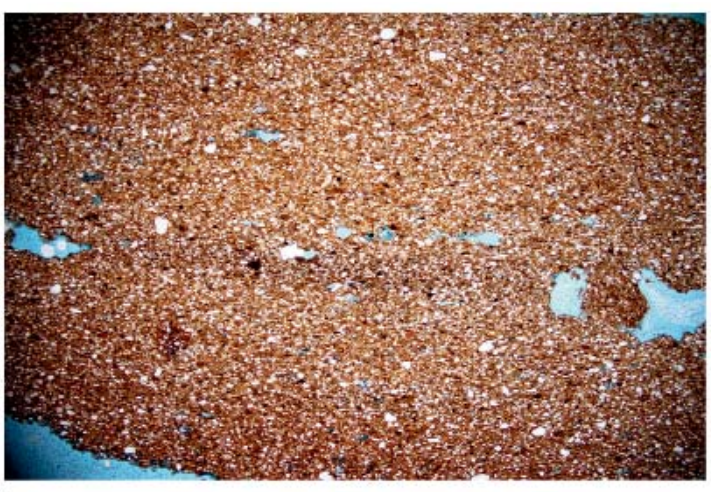

1

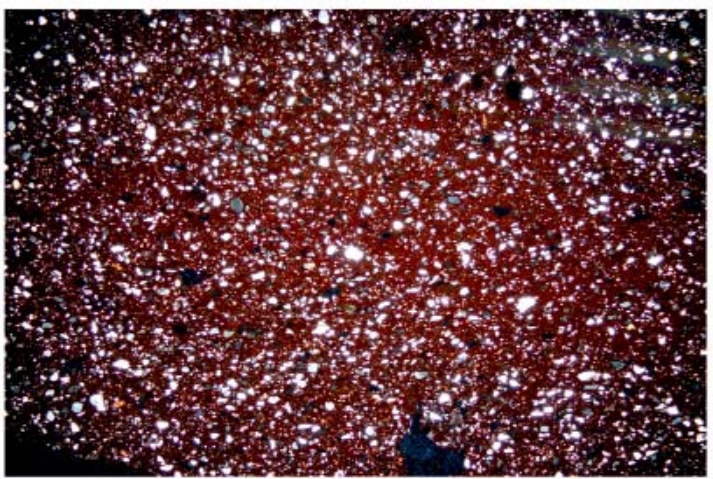

2

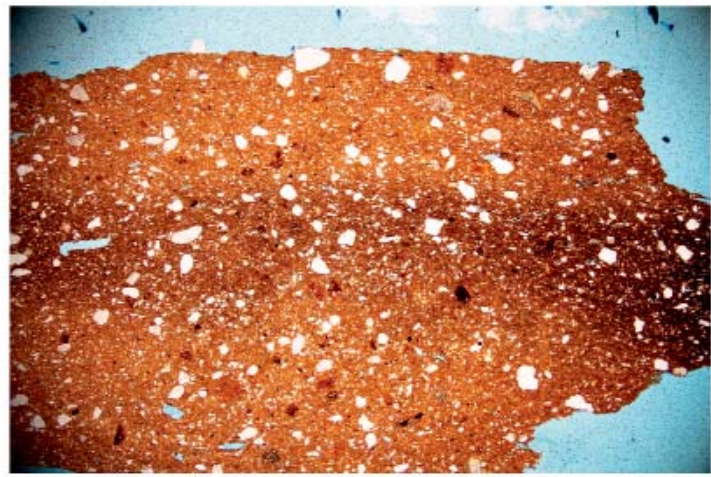

3

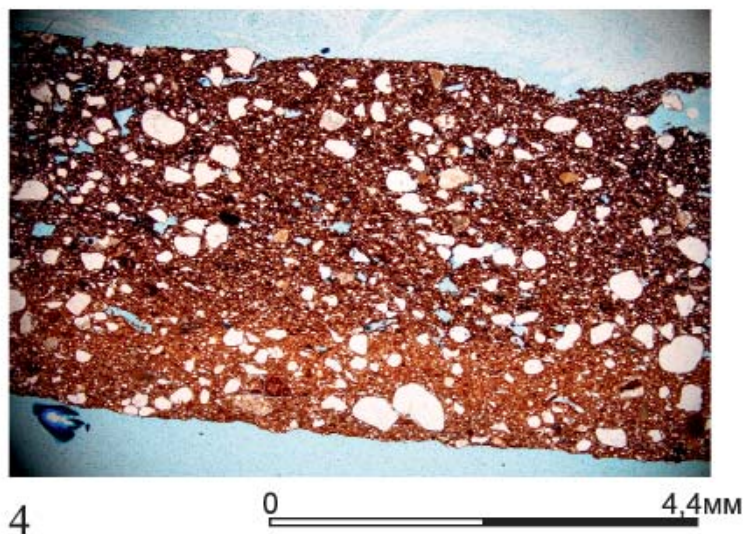

Рис. 1. Обломочная примесь в шлифах керамики I группы, Болгарское городище

Fig. 1. Fragmental admixture in the slides of group I ceramics, Bolgar fortified settlement

Вторая группа имеет псаммитовую примесь более сложного состава. Наряду с кварцем отмечается некоторое количество обломков горных пород кварц-халцедонового состава: яшма, кварцит, фтанит. Характерно, что оптический облик кварца также несколько меняется - появляются зёрна давленого кварца с волнисто-облачным погасанием. Кроме этого, морфология всех обломочных зёрен также меняется: уменьшается степень окатанности, появляется больше угловатых обломков. Данное наблюдение позволяет предположить, что гончарами использовалось как минимум два сырьевых источника песчаной примеси. Для первой группы, вероятно, брался самый доступный волжский песок. Вопрос о географической привязке второго источника остаётся неизученным. По минеральному составу обнаруживаемая в шлифах крупнопсаммитовая примесь наиболее близка к пескам и слабосцементированным песчаникам неогенового возраста, слагающим речные палеодолины вблизи Монастырского оврага (Тетюшский район РТ). Подобные же геологические образования располагаются и на левом берегу Волги недалеко от Болгара.

Анализ совокупных факторов песчаной и алевритовой примеси в исследованных шлифах не выявил очевидных закономерностей. Установлено, что песок добавлялся в глиняное тесто вне зависимости от природного обогащения последнего естественной алевритовой примесью. Следует отметить, что для всех подгрупп «л» (за исключением 3л) и для подгруппы 5т сочетание песчаной и алевритовой примеси очень разнообразно. В подгруппах 1т-4т отмечается более "спокойная” комбинация. Можно предположить, что в последнем случае технология подготовки теста следовала неким традициям, которые устанавливали определённые соотношения в исходной глине и добавляемой примеси. Из всего массива шлифов выделяются образцы подгруппы 3л, в которой (за исключением двух образцов) практически отсутствует искусственная примесь песка и алеврита.

Горные породы в составе обломочной части

Основными породами, уверенно определяемыми в составе обломочной примеси, является группа метаморфических пород кварцхалцедонового состава. Возможно, в шлифах присутствуют обломки и других пород, но малые размеры зёрен не позволяют уверенно и достоверно их определить. Большинство зёрен выделенных пород имеют схожую 


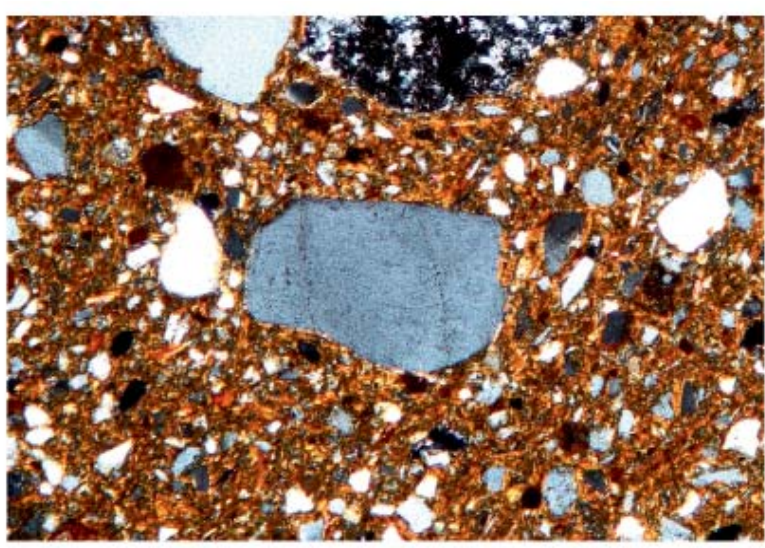

1

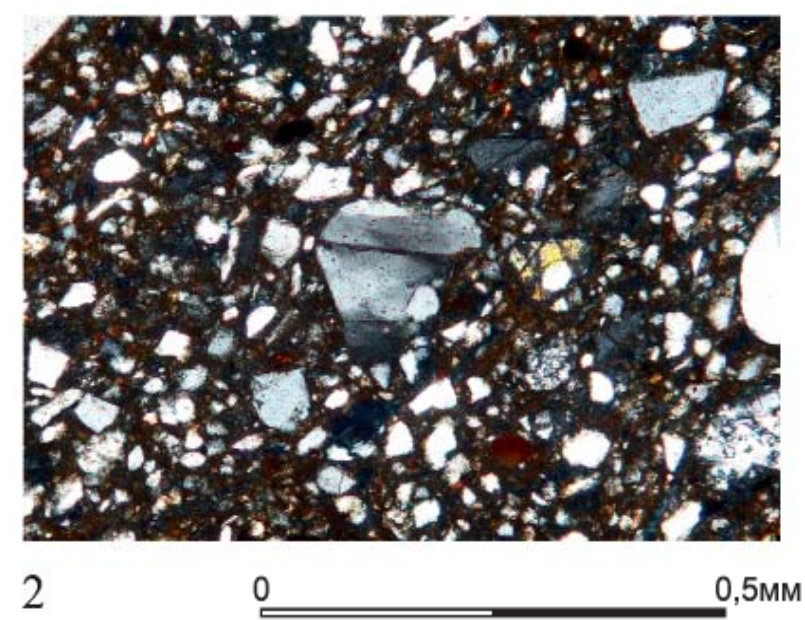

$0,5 \mathrm{мm}$

Рис. 2. Разновидности кварца в шлифах керамики I группы, Болгарское городище

Fig. 2. Varieties of quartz in the slides of group I ceramics, Bolgar fortified settlement

размерность $(0,1-0,3$ мм, значительно реже до 1,0-1,5 мм) и степень окатанности от угловатых, слабоокатанных до среднеокатанных, редко хорошо окатанных. Яшма определяется по характерному соотношению тонко- и скрытокристаллического кварца и глинистого вещества (рис. 3: 1). Фтанит - кремнистая порода со значительным количеством углистых чёрных непрозрачных частиц (рис. 3: 2). Кремнистая порода кварц-халцедонового состава определяется по тонко- и скрытокристаллическому строению (рис. 3: 3). Кварцит с характерным мозаичным строением имеет преимущественно мелкокристаллическую структуру, в отдельных зёрнах наблюдаются отчётливые регенерационные каёмки кварца (рис. 3: 4; 3: 5). Помимо зёрен метаморфических пород кварц-халцедонового состава в значительно меньшем количестве отмечены обломки аргиллитов, как правило, хорошо окатанных (рис. 3: 6).

Третья группа признаков - поровое пространство

Для всех изученных шлифов характерно наличие различного по морфологии порового пространства. Общее количество пор в исследованных шлифах укладывается в следующие диапазоны: слабопористые образцы от 1-2 до 5-10 \% от общей площади шлифа; образцы средней пористости от 10-12 до 15-20\%, сильнопористые образцы от 20\% до 30-35\% пористости. Во всей изученной выборке только у единичных образцов суммарная пористость превышает 30-35\% (например, образец подгруппы 4т № 23.2). Очевидно, что керамика с такими высокими показателями пористости не могла быть прочной и использоваться в быту. Вероятнее всего, подобные обломки являются технологическим браком и должны исключаться из общего анализа.

По морфологии все пустотные образования могут быть разделены на следующие группы.

1. Система мелких удлинённых пор: наблюдаются практически во всех шлифах, размер их варьирует от $0,1 \times 0,5$ до $0,5 \times 1,5$ мм, нередко подобные поры чётко ориентируются по удлинению параллельно краям фрагментов керамики, распределение по площади шлифа равномерное или участками (рис. 4: 1). Предполагаемая причина возникновения подобных пустот связывается с выпариванием воды и уменьшением объёма глиняного теста при сушке и обжиге.

2. Изометричные поры различного размера: встречаются в шлифах значительно реже, имеют размер от $0,05 \times 0,05$ до $1,5 \times 1,5 \mathrm{MM}$, хаотично распределены по площади шлифа, иногда тяготеют к центральным частям обломков (рис. 4: 2). Доминирующим фактором в образовании подобных пор является, видимо, закипание остаточной (после сушки) воды в процессе обжига.

3. Крупные поры: в единичном количестве отмечены во многих образцах, имеют неправильные, часто угловатые формы и размеры от $1,5 \times 2,5$ до $2,0 \times 5,0$ мм, хаотично распределены по площади шлифа (рис. 4: 3). Образуются, по мнению авторов, в момент формирования керамического изделия при “захвате” глиняным тестом пузырьков воздуха.

4. "Поры облегания": предлагаемый авторами термин определяет поровое пространство, образующееся вокруг антропогенных (привнесённых искусственно) зёрен и включений. Фиксируются в шлифах тонкими (до 0,1 мм) прерывистыми или сплошными оторочками по периметру обломков, достоверно 


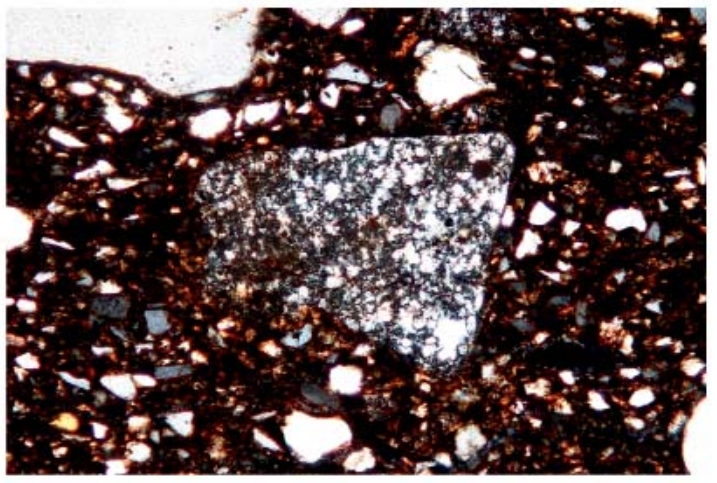

1

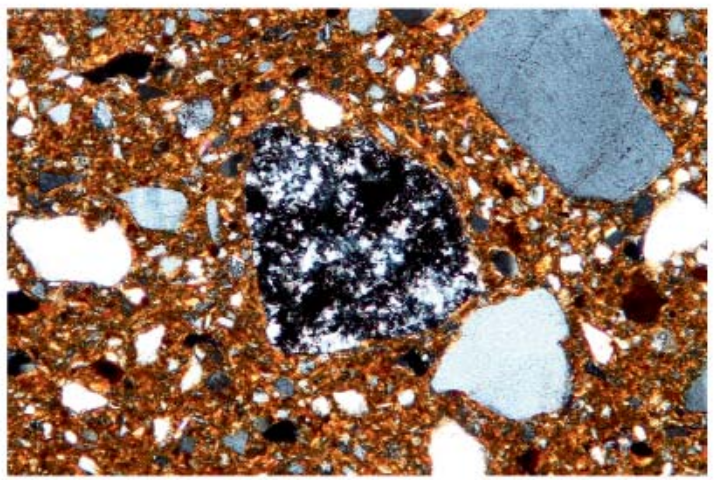

2

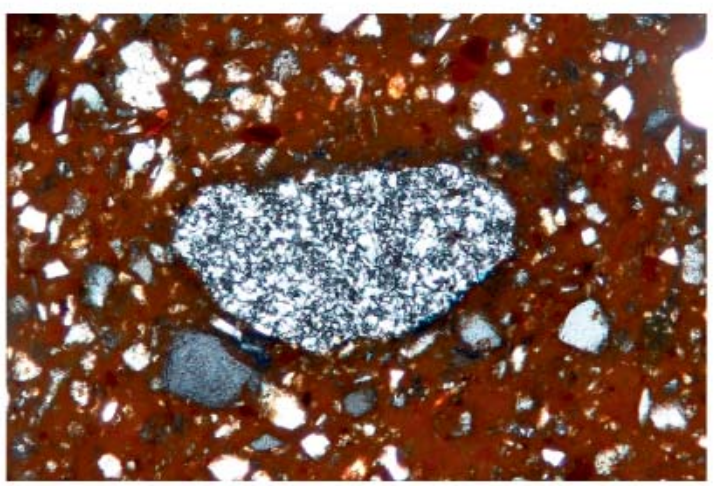

3

0

$0,5 \mathrm{Mm}$

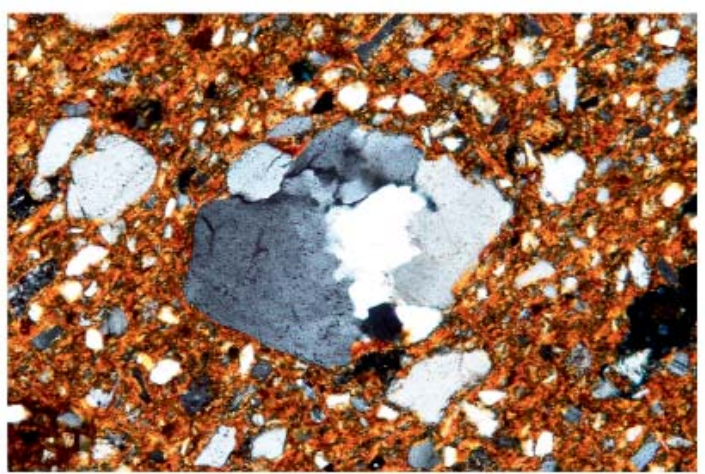

4

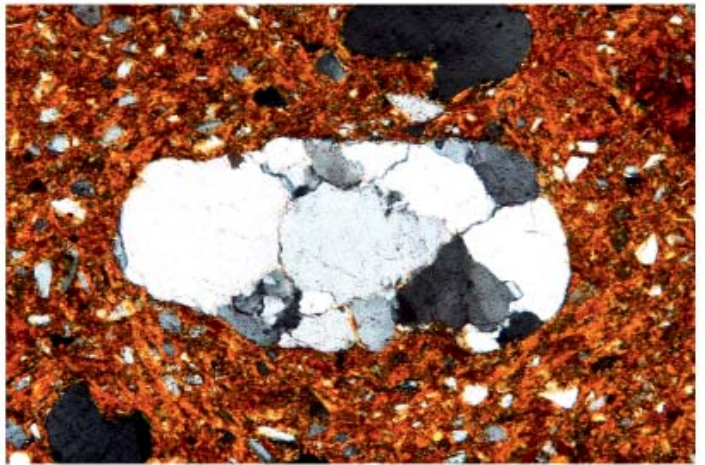

5

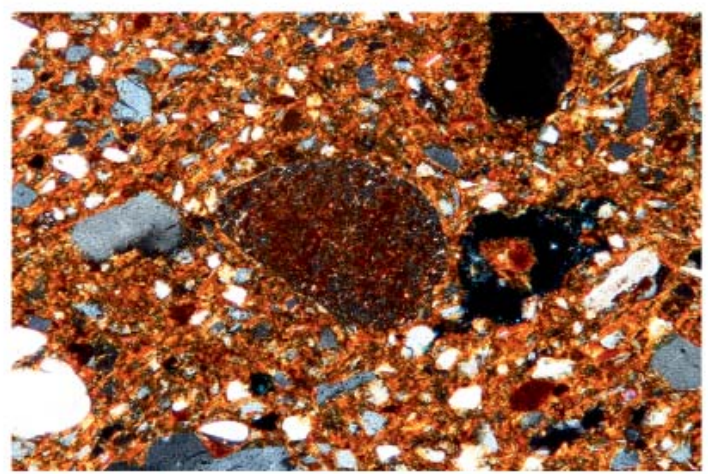

6

$0,5 \mathrm{Mm}$

Рис. 3. Горные породы в составе обломочной части в шлифах керамики I группы, Болгарское городище

Fig. 3. Rocks in the shards and slides of group I ceramics, Bolgar fortified settlement

определяются во многих шлифах, особенно насыщенных псаммитовой примесью и комками шамота (рис. 4: 4). Формирование подобных пустот объясняется отсутствием адгезии глинистого вещества к вновь привнесённым компонентам и уменьшением объёма глиняного теста в процессе сушки и обжига.

5. "Чешуйчатые поры": встречаются практически во всех шлифах ленточных подгрупп и в единичных шлифах тянутых подгрупп, образуют характерную систему мелких (около 0,005×0,1 мм) линзовидных “трещинок”, нередко ориентированных параллельно друг другу или “обтекающих” различные обломки, распределены в шлифах участками (рис. 4: 5). Генезис остаётся невыясненным, возможно, образование подобных пустот объясняется уменьшением объёма некоторых глинистых минералов при дегидратации.

6. Внутренние поры: наблюдаются в единичных шлифах и приурочены исключительно к углифицированной органике и комкам глинистого вещества, характерны неправильные угловатые формы, размер варьирует от первых долей до 0,5-1,0 мм (рис. 4: 6). Образование их предположительно связывается с 


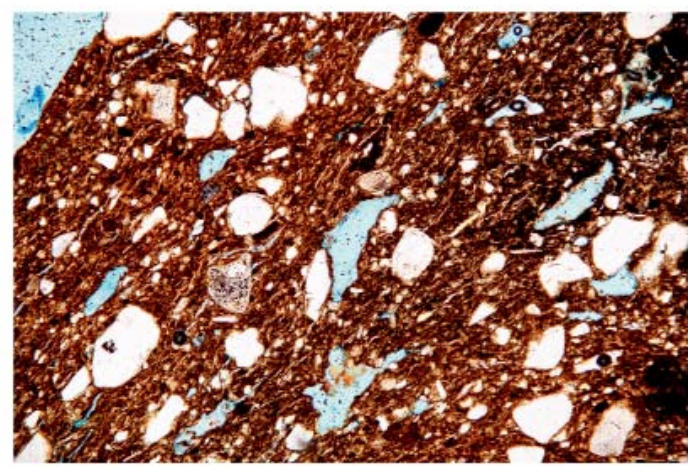

1

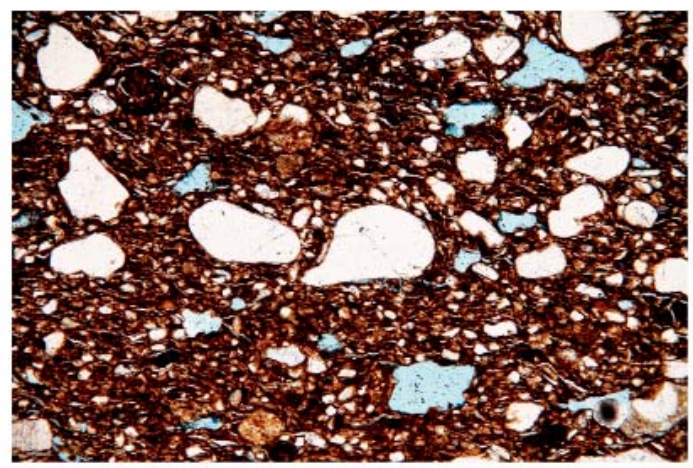

2

0 $0,25 \mathrm{~mm}$

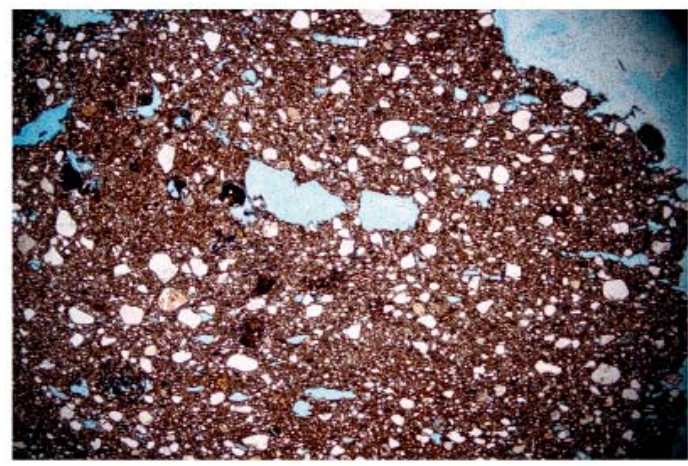

3

0

$1,1 \mathrm{~mm}$

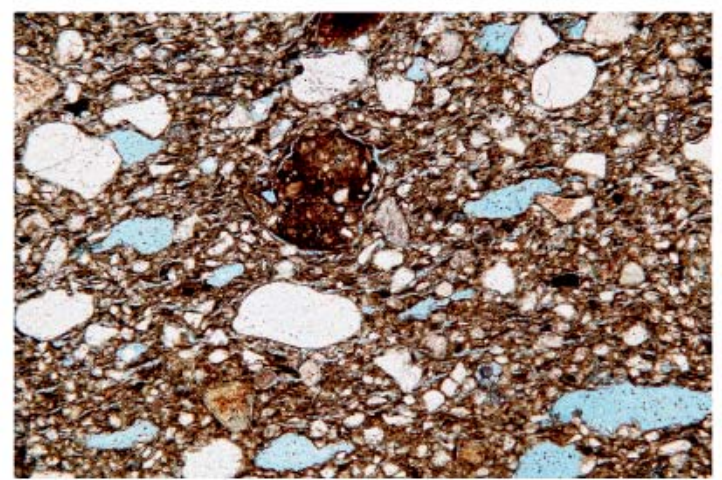

4

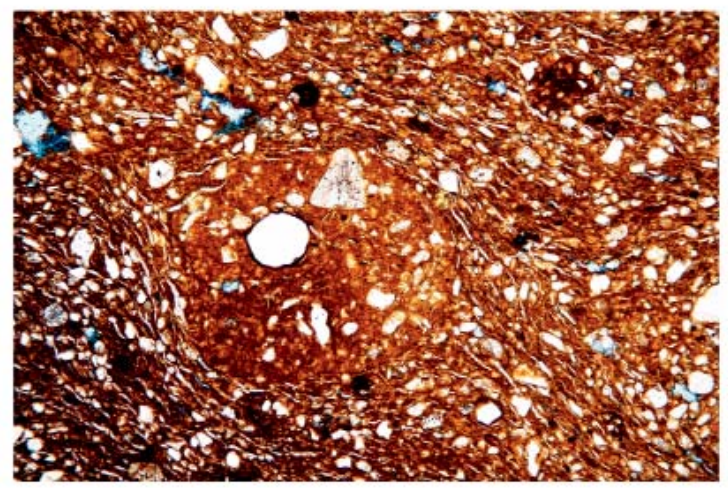

5

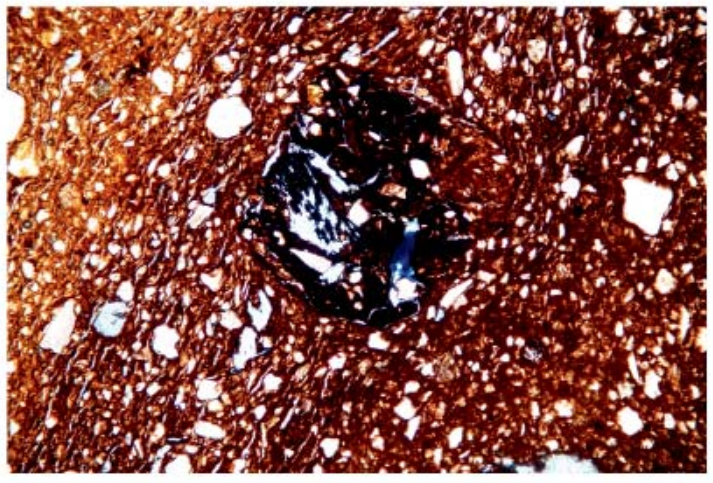

6 $0,25 \mathrm{Mm}$

Рис. 4. Поровое пространство в шлифах керамики I группы, Болгарское городище

Fig. 4. Pore space in the slides of group I ceramics, Bolgar fortified settlement

выгоранием органической привнесённой (и/ или случайно попавшей) примеси и неравномерным изменением объёма комков и основного глинистого вещества в процессе обжига.

Анализ и сравнение порового пространства позволяет ответить на многие вопросы, связанные с производственными процессами формирования, сушки и обжига керамического изделия.

Подводя итоги, стоит отметить, что петрографические исследования 126 шлифов I группы керамики Болгарского городища позволили сделать следующие выводы:
1. При изготовлении керамики использовалось минимум два сырьевых источника глины: первый снабжал гончаров однородным, второй - сгустковым глинистым материалом.

2. В качестве обязательной добавки в глиняное тесто практически во всей исследованной керамике обнаруживается сухая перетёртая глина.

3. Совместный анализ песчаной и алевритовой примеси позволяет предположить наличие некоторых технологических отличий 
в использовании минеральных примесей в тянутых и ленточных подгруппах.
4. Поровое пространство является прямым индикатором технологии формирования гончарного изделия.

\section{Примечание:}

${ }^{1}$ Подготовка шлифов и их описание выполнены сотрудником Лаборатории пробоподготовки Института геологии и нефтегазовых технологий Казанского федерального университета О.Ю. Андрушкевичем.

\section{ЛИТЕРАТУРА}

Бахматова В.Н., Куклина А.А. О связи технологии изготовления общеболгарских керамических сосудов с их функциональным предназначением: характеристика формовочных масс (по материалам исследования Болгарского городища 2011-2012 гг.) // Поволжская археология. 2014. №2(8). С. 230-255.

Внуков С.Ю. Причерноморские амфоры І в. до н.э. - ІІ в. Н.э. Ч. ІІ. Петрография, хронология, проблемы торговли. СПб.: Алетейя, 2006. 320 с.

Герман К.Э., Кулькова М.А. Новые петрографические исследования керамики сперрингс с памятников бассейна Онежского озера // Ученые записки Петрозаводского государственного университета. 2019. № 6 (183). C. 12-21.

Куклина А.А. Неполивная керамика Болгара с раскопов в юго-восточной части городища (по материалам раскопов CCXVI, CCXXI, CСXXIII 2016 г.) // Археология Евразийских степей. 2018. №5. С. 185-192.

Куклина А.А. Новые исследования общеболгарской керамики: историко-культурный подход. // Поволжская археология. 2020. №2. С. 228-237.

Кулькова М.А. Петрографический анализ в оценке формовочных масс при изучении древней глиняной посуды // Самарский научный вестник. 2015. №3 (12). С. 100-107.

\section{Информация об авторах:}

Куклина Анна Александровна, младший научный сотрудник, Институт археологии им. А.Х. Халикова АН РТ (г. Казань, Россия); kuklinanna@mail.ru

Андрушкевич Олег Юрьевич, заведующий Лабораторией, Казанский (Приволжский) федеральный университет (г. Казань, Россия); gemmaol@bk.ru

\section{REFERENCES}

Bakhmatova, V. N., Kuklina, A. A. 2014. In Povolzhskaya arkheologiya (Volga River Region Archaeology) 8 (2), 230-255 (in Russian).

Vnukov, S. Yu. 2006. Prichernomorskie amfory I v. do n.e. - II v. n.e. Ch. 2: Petrografiia, khronologiia, problemy torgovli (Pontic Amphorae of the $1^{\text {st }}$ Century B.C. - the $2^{\text {nd }}$ Century A.D. Part 2: Petrography, Chronology, Trade Issues). Saint Petersburg: "Aleteiia" Publ. (in Russian).

German, K. E., Kulkova, M. A. 2019. In Uchenye zapiski Petrozavodskogo gosudarstvennogo universiteta (Scientific Bulletin of the Petrozavodsk State University) 183 (6). 12-21 (in Russian).

Kulkova, M. A. 2015. In Samarskii nauchnyi vestnik (Samara Scientific Bulletin) 12 (3), 100-107 (in Russian).

Kuklina, A. A. 2018. In Arkheologiya evraziiskikh stepei (Archaeology of Eurasian Steppes) 4. 185-192 (in Russian).

Kuklina, A. A. 2020. In Povolzhskaya arkheologiya (Volga River Region Archaeology) 32 (2), 228-237 (in Russian).

\section{About the Authors:}

Kuklina Anna A. Institute of Archaeology named after A.Kh. Khalikov, Academy of Sciences of the Republic of Tatarstan. Butlerov St., 30, Kazan, 420012, Republic of Tatarstan, Russian Federation; kuklinanna@ mail.ru

Andrushkevich Oleg Yu. Kazan (Volga Region) Federal University. Kremlyovskaya str., 18, Kazan, 420008, Republic of Tatarstan, Russian Federation; gemmaol@bk.ru

Статья поступила в журнал 01.04.2021 г. Статья принята к публикации 01.04.2021 г. Авторы внесли равноценный вклад в работу. 